\title{
Delta Flower Beetle Trigonopeltastes delta (Forster 1771) (Insecta: Coleoptera: Scarabaeidae : Cetoniinae : Tribe, Trichiini) ${ }^{1}$
}

\author{
Brandon Jones and Andrea Lucky²
}

\section{Introduction}

The delta flower beetle, Trigonopeltastes delta (Forster), is a member of the scarab beetle family Scarabaeidae, in the subfamily Cetoniinae. This subfamily is commonly known as flower or fruit chafers because their diet consists mostly of decomposing fruits or pollen (Cave and Ratcliffe 2008). Trigonopeltastes delta belongs to the tribe Trichiini, which contains mostly flower-frequenting species. Although this species is commonly encountered where it occurs, many details of its life cycle and its potential economic importance remain poorly studied. Like many other cetoniines, the delta flower beetle has bright colors and distinctive patterns that distinguish it from other similar species (Figure 1).

The delta flower beetle is one of two species in Florida, but while Trigonopeltastes delta is a familiar sight, Trigonopeltastes floridana is extremely rare (Woodruff 1960). While they are superficially similar, these species are distinguished by distinctive yellow markings on the pronotum. Trigonopeltastes delta bears a triangular mark whereas Trigonopeltastes floridana has a U- or V-shaped mark.

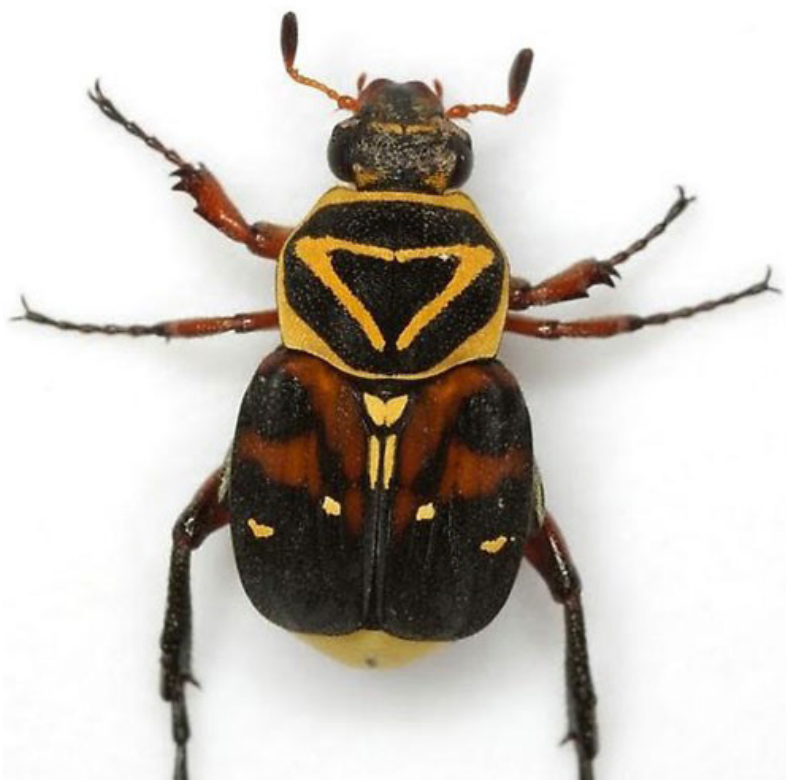

Figure 1. Adult Trigonopeltastes delta (Forster) (dorsal view). Credits: Mike Quinn, TexasEnto.net

\section{Etymology and Synonymy}

The name Trigonopeltastes delta is Greek in origin and describes the pronotal markings of the species. Trigon translates to triangle, pelt translates to a shield, and delta originates from the letter $\Delta$, or delta. The Greek symbol for delta is a triangle, which resembles the beetle's pronotal marking, and accounts for its common name.

1. This document is EENY-704, one of a series of the Department of Entomology and Nematology, UF/IFAS Extension. Original publication date April 2018. Visit the EDIS website at http://edis.ifas.ufl.edu. This document is also available on the Featured Creatures website at http://entomology.ifas.ufl. edu/creatures.

2. Brandon Jones; and Andrea Lucky, Department of Entomology and Nematology; UF/IFAS Extension, Gainesville, FL 32611.

The Institute of Food and Agricultural Sciences (IFAS) is an Equal Opportunity Institution authorized to provide research, educational information and other services only to individuals and institutions that function with non-discrimination with respect to race, creed, color, religion, age, disability, sex, sexual orientation, marital status, national origin, political opinions or affiliations. For more information on obtaining other UF/IFAS Extension publications, contact your county's UF/IFAS Extension office. 
The species was originally described as Scarabaeus delta by Johann Reinhold Forster in 1771 and was later transferred to the genus Trigonopeltastes (Smith 2004).

\section{Distribution}

The delta flower beetle is commonly found throughout the southeastern United States from Florida to eastern Texas, but has been documented as far north as New Jersey and westwards to Kansas (Figure 2) (Peck and Thomas 1998).

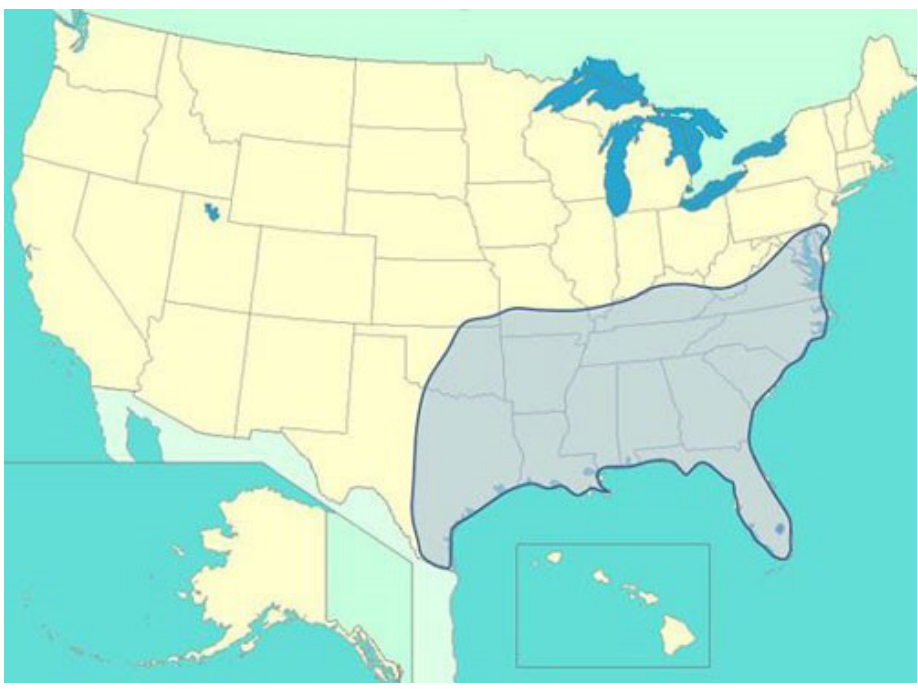

Figure 2. Distribution of Trigonopeltastes delta (Forster) within the United States.

Credits: Brandon Jones, modified from description of Peck and Thomas (1998)

\section{Description and Life Cycle}

Not all the life stages of Trigonopeltastes delta have been studied, but it is expected to exhibit similar general life history patterns of others members in the same subfamily. The descriptions below relate generally to the subfamily Cetoniinae.

\section{Eggs}

Within the subfamily Cetoniinae eggs are typically only a few millimeters long, oval in shape, and white to dirty white in coloration (Hayes 1925; Kumbhar et al. 2012).

\section{Larvae}

Scarabaeid larvae are typically scarabaeiform in shape (i.e., curled up, or C shaped). Shabalin and Bezborodov (2008) documented three different species within the subfamily Trichiinae as having three larval instars. Each of the species has a white to pale, robust body and a darker brown head. Trigonopeltastes delta third instar larvae were described as having a smooth cranium and a head capsule width around $3.7 \mathrm{~mm}$. The frons (middle portion of insect face) was described as having two posterior setae (bristlelike hair), a single exterior seta, a single anterior frontal seta, and a single anterior angle seta. The dorsal (backside) portion of the abdominal segments consists of 9-10 unfused segments (Ritcher 1966).

\section{Pupae}

During pupation scarab beetles will move 2 to $25 \mathrm{~cm}$ down into the soil and create a pupal chamber. During pupation they are often yellow or brown in color (Goodyer and Nicholas 2007). Adult beetles emerge after 3 to 6 weeks.

\section{Adults}

Adults are around $8-11 \mathrm{~mm}$ in length, with an abdomen greater in length than width. They have a black head and a mostly reddish-brown clypeus (anterior section of head, below the frons) (Figure 3) (Smith 2016). Flower beetles have weakly developed mandibles (mouthparts) which are hidden by the clypeus (Figure 3 ). The antennae are lamellate (shaped like an asymmetrical club) (Figure 1) and consist of 10 segments (Arnett et al. 2002). Adult males and females can be distinguished from each other using several characteristics. Males have bidentate (two toothed) anterior tibiae whereas those of females are tridentate (three toothed). The posterior femur of males is more swollen and twisted than those of females. The male pronotum is smoother, less colorful, and more velvety than those of the females (Woodruff 1960). Adult Cetoniinae have weak mandibles (mouthparts) and are adapted to feeding on pollen or sap of woody plants (Hayes 1925).

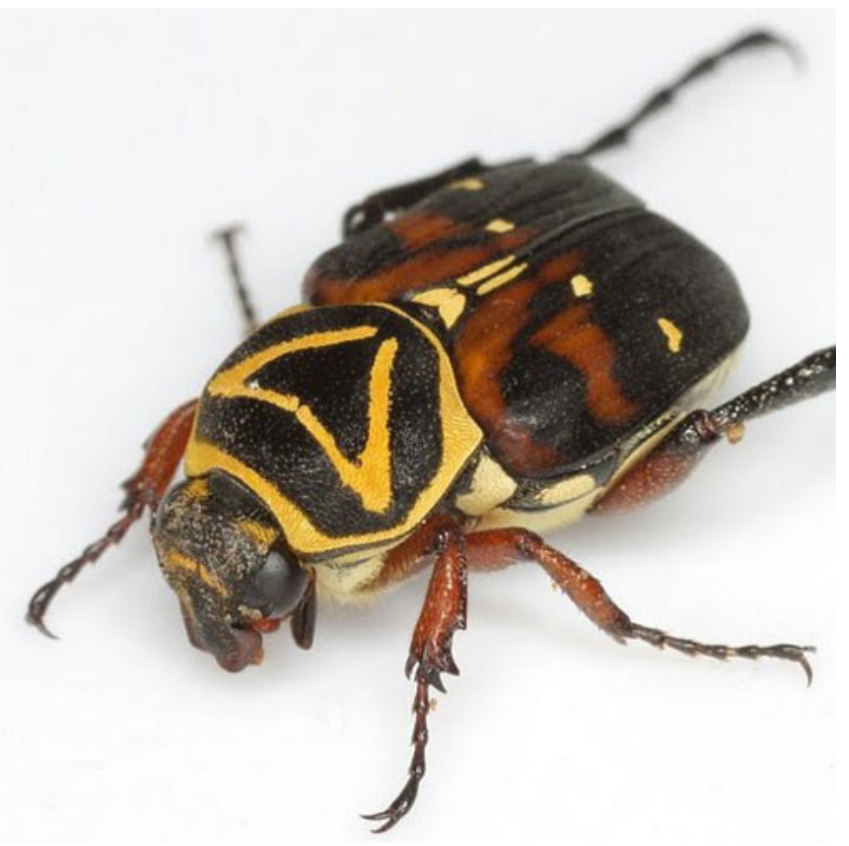

Figure 3. Adult male Trigonopeltastes delta (Forster) (anterior view) showing clypeus.

Credits: Mike Quinn, TexasEnto.net via www.bugguide.net 
The color pattern is somewhat similar to some wasp species and may be a form of Batesian mimicry.

Like other holometabolous insects, delta flower beetles have four life stages; egg, larvae, pupa, adult. Beetles within the Cetoniinae typically take around one year to reach the adult stage (Hayes 1925).

Members of the subfamily Cetoniinae in the southeastern United States lay their eggs in the soil around mid-summer and larvae begin emerging approximately 10 days later (Hayes 1925).

Flower beetles remain in their larval stage longer than any other life stage. It is during this period that they overwinter and feed on wood or decaying organic matter. Records taken around Gainesville, Florida have shown Trigonopeltastes delta larvae within oak stumps (Dozier 1920), and in southern Florida, within the bromeliad species (Tillandsia utriculata Linnaeus) (Cave 2005).

Within Florida and throughout the southeast, cetoniine pupation begins in early May within the soil and lasts approximately 20 days (Hayes 1925).

Once adults emerge, delta flower beetles fly from May through August (Howden 1968). Adult males are typically three times more abundant than females (Woodruff 1960).

Delta flower beetles are diurnal (active during daylight). Throughout much of their adult life, they are commonly found on and near flowers within tall grass and meadows. Their adult life revolves completely around flowers. Mating occurs on flowers (Figure 4) and their adult diet consists mostly of pollen (Smith 2016). Pascarella et al. (2001) found the delta flower beetle to be extremely common on flowers throughout Everglades National Park.

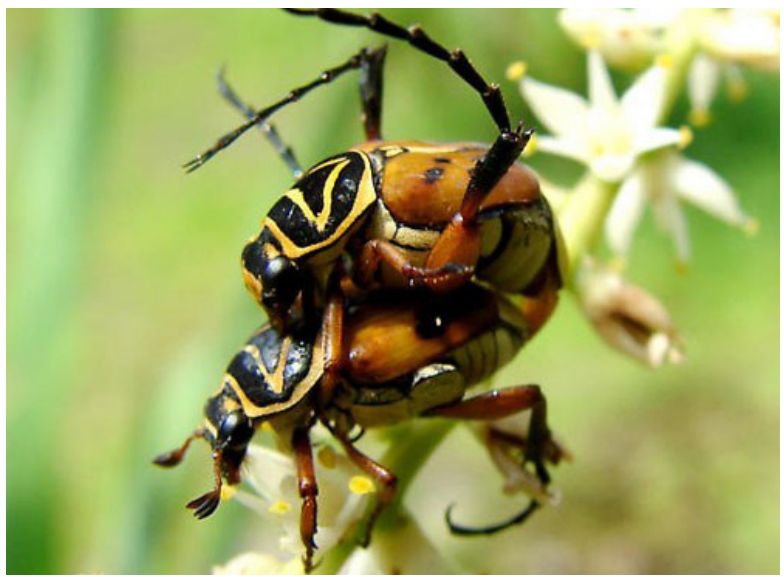

Figure 4. Adult male and female Trigonopeltastes delta (Forster) mating on needle palm Rhaphidophyllum hystrix (Wendl and Drude). Credits: Rick Miller, www.bugguide.net

\section{Hosts}

A range of flowering plants serve as hosts for Trigonopeltastes delta adults. Both pollen feeding and mating occur on flowering plants. They have been recorded on Codiaeum variegatum Blum (croton bud), Hibiscus rosa-sinensis L. (hibiscus), Rosa sp. (rose), Rhus leucantha Jacq. (southern sumac), Mangifera indica L. (mango), Thuja sp. (arborvitae), Ligustrum japonicum Thunb. (privet), Severinia buxifolia Ten. (boxthorn), Ceiba pentandra Gaertn. ("kapok"), Persea americana Mill. (avocado), Sabal palmetto Lodd. (cabbage palm), Litchi chinensis Sonner (lychee), Vanda sp. (orchid), Crotalaria sp. (crotalaria), Quercus muehlenbergii Engelm. (chinkapin oak), Citrus sp., Magnolia sp. (bay), Dianthus sp. (carnation), Euphorbia sp. (poinsettia), Cephalanthus occidentalis L. (button-wood), Senecio sp. (groundsel), Ipomoea sp. (morning glory), Zizyphus sp. (jujube), Schinus sp. (Brazilian pepper), Casimiroa edulis L. and L. (white sapota), Cyrilla racemiflora L. (leatherwood), Elephantopus elatus Bertol (elephant-foot), Daucus carota L. (cultivated carrot), Ilex glabra Gray (inkberry) Rhus copallinum L. (shining sumac), Lachnanthes tinctoria (Walt.) Ell. (red-root), and Ceanothus americana L. (New Jersey tea) (Woodruff 1960). Their host preference extends beyond this list and most likely includes many other flowering plants (Figure 5).

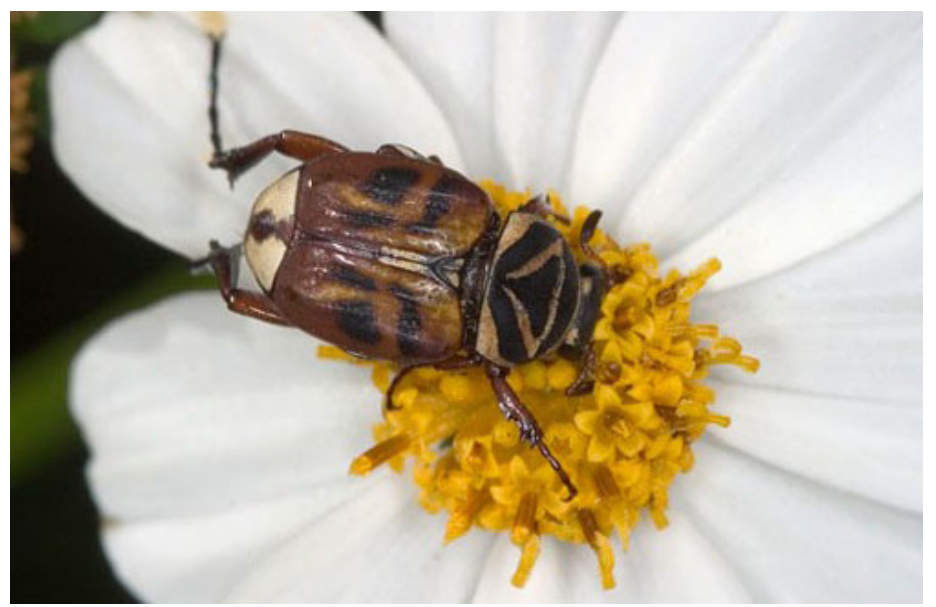

Figure 5. Adult Trigonopeltastes delta (Forster) (dorsal view) feeding on Bidens alba (de Candolle) flower.

Credits: Alan Chin-Lee, www.bugguide.new

\section{Economic Importance}

Although the larvae of many other species in the subfamily Cetoniinae can have devastating economic impacts as a result of the phytophagous (plant feeding) nature of their larval stages (Hayes 1925), the larvae of delta flower beetles are not known to cause any major damage. This is most likely because their larval diet consists of decaying wood and organic matter (Ritcher 1958). This species is thought 
to be an important pollinator in native ecosystems as it is commonly found on a wide range of flowering hosts (Woodruff 1960). This species is a colorful, common native that is in need of further study.

\section{Selected References}

Arnett Jr RH, Thomas MC, Skelley PE, Frank JH. 2002.

American Beetles, volume II: Polyphaga: Scarabaeoidea through Curculionoidea. Boca Raton, FL: CRC Press LLC.

Cave RD. 2005. “Trigonopeltastes delta (Coleoptera: Scarabaeidae: Cetoniinae) larva developing in a bromeliad terrarium." The Coleopterists Bulletin 59(4): 527-528.

Cave RD, Ratcliffe BC. 2008. "Scarab beetles (Coleoptera: Scarabaeoidae)." In, J. Capinera, Encyclopedia of Entomology, 2nd Edition. Springer Netherlands 3273-3286.

Dozier HL. 1920. "An ecological study of hammock and piney woods insects in Florida." Annals of the Entomological Society of America 13: 325-380.

Goodyer GJ, Nicholas A. 2007. Scarab grubs in northern tableland pastures. NSW Department of Primary Industries. Primefact 512: 1-8.

Hayes WP. 1925. A comparative study of the history of certain phytophagous scarabaeid beetles. Kansas State Agricultural College. Technical Bulletin 16.

Howden HF. 1968. "A review of the Trichiinae of North and Central America (Coleoptera: Scarabaeidae)." Memoirs of the Entomological Society of Canada 54: 1-77.

Kumbhar SM, Mamlayya AB, Patil SJ, Bhawane GP. 2012. "Biology of Chiloloba orientalis." Journal of Science 12: 1-15.

Pascarella JB, Waddington KD, Neal PR. 2001. "Non-apoid flower-visiting fauna of Everglades National Park, Florida." Biodiversity and Conservation 10: 551-566.

Peck SB, Thomas MC.1998. "A distributional checklist of the beetles (Coleoptera) of Florida." Arthropods of Florida and Neighboring Land Areas. Florida Department of Agriculture and Consumer Services 16.

Ritcher PO. 1958. "Biology of Scarabaeidae." Annual Review of Entomology 3: 331-334.

Ritcher PO. 1966. White grubs and their allies, a study of North American Scarabaeoid larvae. Oregon State University Monograph Series No. 4: 1-219.
Shabalin SA, Bezborodov VG. 2008. "Larvae of scarab beetles of the subfamily Trichiinae (Coleoptera, Scarabaeidae) from the Russian Far East." Entomological Review 89: 1131-1136.

Smith ABT. 2003. "Clarification on the nomenclatural status of six genus - group names in the tribe Trichiini (Coleoptera: Scarabaeidae: Cetoniiae)." The Coleopterists Bulletin 58(2): 285-291.

Smith ABT. 2016. "Five new species of Trigonopeltastes Burmeister and Schaum from Central America with new country records for other New World Trichiini (Coleoptera, Scarabaeidae, Cetoniinae)." Zookeys 617: 91-127.

Woodruff RE. 1960. "Suppression of the genus Roplisa Casey with notes on the United States species of Trigonopeltastes Burmeister (Coleoptera: Scarabaeidae)." Florida Entomologist 43: 139-145. 